\title{
Characterization of golden-cheeked warbler Dendroica chrysoparia habitat at Fort Hood, Texas, USA
}

\author{
Verl R. Emrick ${ }^{1, *}$, Scott Tweddale ${ }^{2}$, Michael St. Germain ${ }^{1}$ \\ ${ }^{1}$ Conservation Management Institute, Virginia Polytechnic Institute and State University, 1900 Kraft Drive, Suite 250, \\ Blacksburg, Virginia, 24061, USA \\ ${ }^{2}$ USACERL Champaign, Illinois, PO Box 9005, Champaign, Illinois 61826-9005, USA
}

\begin{abstract}
The golden-cheeked warbler Dendroica chrysoparia is a federally endangered, neotropical-nearctic migrant songbird that breeds in central Texas, USA, and prefers mature, closed canopy oak-Ashe juniper woodlands for nesting and foraging. Fort Hood is an 87890 ha military reservation located in central Texas in Bell and Coryell Counties on the eastern edge of the Edwards Plateau ecoregion. We surveyed for golden-cheeked warblers and measured habitat variables at 95 separate locations in a $56.6 \mathrm{~km}^{2}$ research area that supports a golden-cheeked warbler breeding population. We detected golden-cheeked warblers on 34 of 95 (36\%) point count locations. Principal component analysis was used to reduce the 27 habitat variables to a set of uncorrelated variables. This analysis resulted in the identification of 4 principal components that accounted for $52 \%$ of the variance. Logistic regression identified one principal component (ratio of Ashe juniper to other woody species) that was strongly related to golden-cheeked warbler occurrence. Our data indicate that a 4:1 ratio of Ashe juniper to other woody species is an important feature of occupied golden cheekedwarbler habitat, particularly in the mid- to upper canopy at Fort Hood.
\end{abstract}

KEY WORDS: Golden-cheeked warbler • Ashe juniper $\cdot$ Habitat $•$ Military training

\section{INTRODUCTION}

The golden-cheeked warbler Dendroica chrysoparia is a federally endangered, neotropical-nearctic migrant songbird that breeds in central Texas, USA. The males have bright yellow cheeks interrupted by a black line through each eye, a white lower breast and belly, and are black except for white bars and edging on the wings. The females' cheeks are duller yellow, with more white on the underside, and dark olive green backs. Pulich (1976) estimated that golden-cheeked warblers had a breeding population of less than 15000 individuals. The United States Fish and Wildlife Service (USFWS) listed golden-cheeked warblers as federally endangered in 1990 (USFWS 1992). The major cause identified for their decline was the loss of breeding habitat due to urban development and conversion of land to agriculture (USFWS 1992, Anders \& Dearborn
2004). Habitat fragmentation and nest parasitism by brown-headed cowbirds Molothrus ater are other threats to golden-cheeked warblers (USFWS 1992)

The range of breeding habitat for golden-cheeked warblers coincides closely with the distribution of Ashe juniper Juniperus ashei (Pulich 1976). Goldencheeked warblers prefer mature, closed canopy oakAshe juniper woodlands for nesting and foraging (Ladd 1985, USFWS 1992, Lockwood 1996, Jetté et al. 1998, Magness et al. 2006). Ashe juniper is the most important component in golden-cheeked warbler habitat, with several species of oak playing an important role in foraging (Kroll 1980, Ladd 1985). Nests frequently occur within Ashe juniper trees between a height of 3 and $7 \mathrm{~m}$, but are occasionally found in other species in close proximity (Ladd 1985, USFWS 1992). Ashe juniper bark begins to peel once it reaches maturity, and female golden-cheeked warblers use strips of 
mature Ashe juniper bark for construction of their nests. In addition, males have been observed offering Ashe juniper bark as part of the courtship ritual (Lockwood 1996). R. Wahl et al. (unpubl.) characterized golden-cheeked warbler habitat as closed canopy with a moderate to high density of trees and dense foliage, usually at higher levels in the canopy. However, habitat studies conducted across the range of the species have produced inconsistent results (USFWS 1992).

Although it is generally recognized that mature, closed canopy oak-Ashe juniper woodlands provide habitat for golden-cheeked warblers, there is still considerable variability in habitat composition and structure among the sites. Therefore, an assessment of the habitat composition and structure among Ashe juniper-oak woodland patches where golden-cheeked warblers are found may help identify critical habitat features necessary for conservation and the development of management and recovery plans for this species.

Our study objective was to identify habitat variables that differed between locations occupied by goldencheeked warblers and those not occupied within mature oak-Ashe juniper woodlands at Fort Hood, Texas. This study was part of a larger research effort to identify potentially important habitat variables that could be identified through remote sensing and used to parameterize a landscape level habitat model for golden-cheeked warblers.

\section{MATERIALS AND METHODS}

Study area. Fort Hood is an 87890 ha military reservation located in central Texas in Bell and Coryell Counties on the eastern edge of the Edward's Plateau ecoregion (Hayden et al. 2001). It is the largest active duty armored post in the United States, supporting 2 full armored divisions (First Cavalry Division and 4th Infantry Division) and numerous smaller military units and organizations. Fort Hood lies in the Lampasas Cutplains physiographic province, which is characterized by broad valleys, rolling hills, and wide stream divides. Soils in the region developed from underlying limestone parent material and range from the shallow and rocky Inceptisols on the slopes to the deep, organicmatter rich Mollisols in the valleys and flats (Tazik et al. 1993). Long hot summers and short, mild winters typify the climate of the Fort Hood region. The average low temperature in January is $1^{\circ} \mathrm{C}$, and the average high temperature in August is $36^{\circ} \mathrm{C}$. The average annual rainfall is $87 \mathrm{~cm}$, with the largest amount occurring in May. Vegetation consists of a mix of woodlands and grasslands. Common trees found at Fort Hood include Texas oak Quercus texana and Ashe juniper, with a variety of other oaks intermingled throughout. Because of heavy grazing and military activity, the grasslands of Fort Hood are dominated by Texas winter grass Stipa leucotrichia and prairie dropseed Sporobolus asper (Tazik et al. 1993). Fort Hood contains the largest breeding population of golden-cheeked warblers managed by a single landowner, and long-term data indicate that the population is increasing (Anders \& Dearborn 2004).

Field data collection. We selected a $56.6 \mathrm{~km}^{2}$ research area in the western portion of Fort Hood that supports a golden-cheeked warbler breeding population (Fig. 1). The research area is subjected to landscape disturbances from military maneuver exercises, which has resulted in a fragmented landscape with a complex matrix of deforested areas, edge vegetation, and mature mixed deciduous-Ashe juniper woodlands. We developed a general land cover map from multi-spectral imagery that identified potential golden-cheeked warbler habitat (i.e. mature, mixed deciduous-Ashe juniper woodlands). Within potential wood- land habitat identified, we randomly allocated points that would serve as the basis for both the habi-
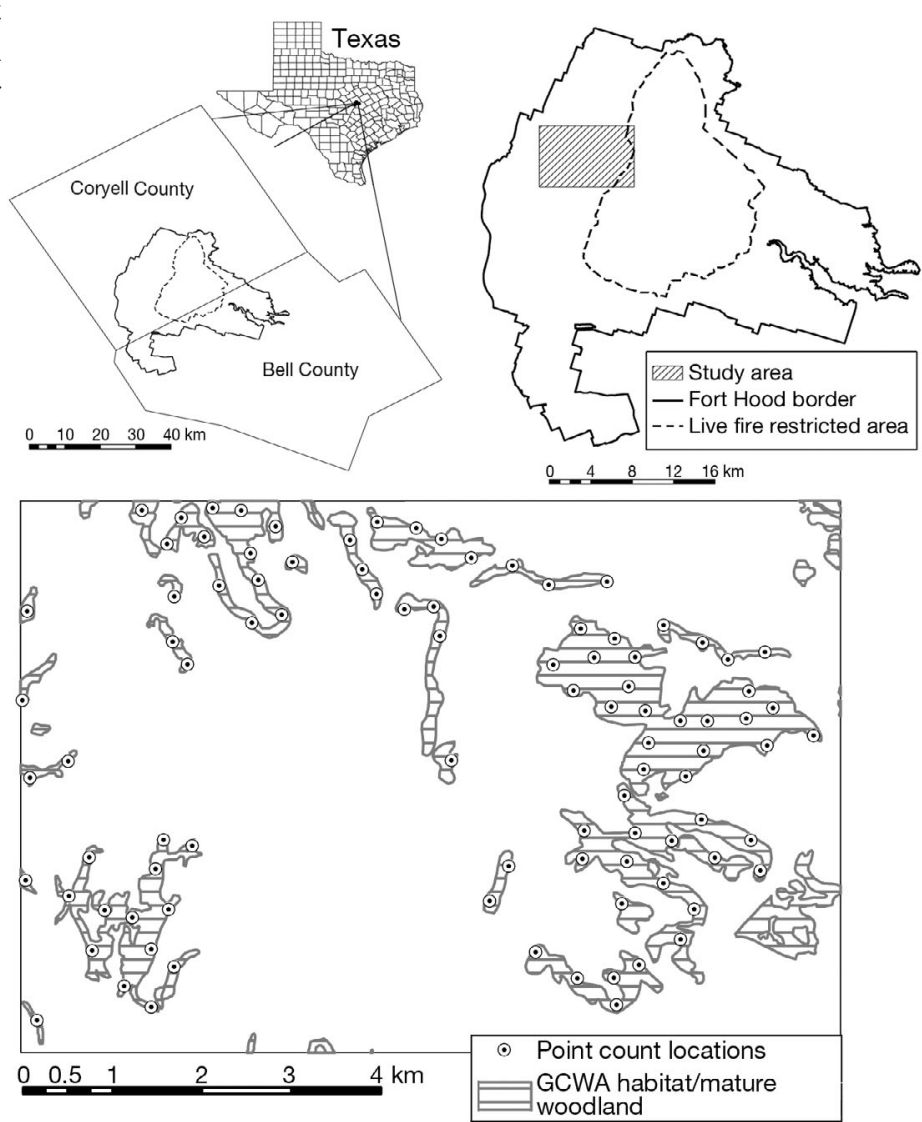

Fig. 1. Dendroica chrysopario. Golden-cheeked warbler (GCWA) study area Fort Hood, Texas, USA 
tat assessment and avian survey. Avian survey techniques followed the guidelines established by Ralph et al. (1995a). To avoid double counting, we allocated points using a minimum distance of $250 \mathrm{~m}$ between each point, which is the standard technique for the region (Ralph et al. 1995b). Although golden-cheeked warblers can be found in woodland edge, this species is not edge dependent as it is frequently found in dense woodland vegetation away from natural or man-made edges (Tazik et al. 1992). Therefore, to avoid edge effects during the avian survey, we buffered each point $50 \mathrm{~m}$ from the edge to ensure that all points were well within woodlands identified as potential habitat. A total of 95 point count stations were allocated and visited from 3 to 14 April 2004, with each station visited on 2 separate occasions by different observers (Ralph et al. 1995b). The point count duration was 6 min with a variable radius to $50 \mathrm{~m}$ following a previously established protocol for sampling golden-cheeked warblers at Fort Hood (Anders \& Dearborn 2004). We placed each avian observation into 1 of the following distance classes: 1: 0-10 m, 2: 10-20 m, 3: 20-30 m, 4: 30-40 m, and 5: $40-50 \mathrm{~m}$.

At each point, we collected habitat variables in an $11.3 \mathrm{~m}$ radius circular plot. Within the plot, we tallied and identified all woody species whose main stem was greater than $10 \mathrm{~cm}$ in diameter at breast height (dbh) and placed each individual into 1 of 4 canopy position classes. Canopy classes were as follows: (1) emergent, crowns clearly higher than surrounding canopy with significant exposure of lateral crown; (2) dominant, top of crown and portion of lateral crown exposed to direct sunlight; (3) subdominant, only top of crown exposed to sunlight; and (4) suppressed, crown completely overtopped by other species. We measured total canopy closure at the plot center using a concave spherical stand densiometer. Vegetative cover for each species in the plot was visually estimated using a modified Braun-Blanquet cover abundance scale (+: $0-1 \%$; 1 : $1-5 \%$; 2: 5-25\%; 3: 25-50\% ; 4: 50-75\%; 5: 75-95\%; 6: 95-100\%) in the following height strata: A, 0-2 m; B, 2-4 m; C, 4-6 m; D, 6-8 m; and E, 8+ m (MuellerDombois \& Ellenberg 1974). We also estimated total cover of leaf litter, herbaceous species, graminoids, and bare ground/rock within the plot using the same Braun-Blanquet cover abundance scale.

Data analysis. The patchy nature of habitats in the study area caused many of the avian point counts to cross habitat types. Furthermore, the density of woody vegetation limited the ability of the point count observers to identify general habitat conditions at a distance of $>30 \mathrm{~m}$. Therefore, we only used avian point count data from a $20 \mathrm{~m}$ radius from the plot center to ensure that the golden-cheeked warbler detection data corresponded to the habitat variables we measured.
If golden-cheeked warblers were detected on either of the 2 visits within $20 \mathrm{~m}$ of the plot center, we counted the species as present at that location. We summarized raw habitat data in the following manner: (1) density $\mathrm{m}^{-2}$ of all woody species; (2) mean dbh of dominant and emergent Ashe juniper; (3) total aerial vegetative cover of Ashe juniper; (4) ratio of total cover of Ashe juniper to total cover of all other woody species; (5) Ashe juniper cover by height strata; and (6) ratio of Ashe juniper vegetative cover to all other species by height strata. The data summarizations resulted in 27 variables that we used to investigate golden-cheeked warbler occurrence and habitat (Table 1). Because many of the habitat variables were correlated, we used principal component analysis (PCA) to reduce the original 27 habitat variables to a set of uncorrelated variables. The principal components (PCs) derived from the PCA were rotated using Varimax (SYSTAT Software). We used the habitat PCs derived from the PCA as independent variables and the golden-cheeked warbler occurrence data as the dependent variables. We subsequently used a multiple stepwise logistic regression (forward selection) analysis to examine the strength of the relationship between habitat variables derived from PCA and occurrence of golden-cheeked warblers. All analyses were performed in SYSTAT 11.0 (SYSTAT Software).

\section{RESULTS}

We detected golden-cheeked warblers within a $20 \mathrm{~m}$ radius of the plot center on 34 of 95 (36\%) point count locations. Golden-cheeked warblers generally occurred in habitats that were higher in total Ashe juniper cover (128\% compared to $112 \%$ for unoccupied habitat) and had a higher ratio of Ashe juniper to hardwoods (Table 1). However, total vegetative cover was higher in unoccupied habitats.

The results of PCA showed that there were 8 PCs with eigenvalues $>1$. Using a scree criterion, we determined that only the first 4 PCs were readily interpretable and biologically meaningful. Each of these PCs consisted of a set of original habitat variables that were ecologically related and explained $52 \%$ of the total variance (Table 2). The first habitat PC (PC-1) represented a gradient in stand composition in terms of the ratio of Ashe juniper to hardwoods and total hardwood cover. Habitats that had a higher ratio of Ashe juniper to hardwoods were positively related to PC-1 (Table 2). The second PC (PC-2) was related to total vegetative cover and the cover of Ashe juniper in the upper canopy. Habitats with higher total cover and higher juniper cover in the upper canopy were positively associated with PC-2. PC-3 was associated with 
Table 1. Dendroica chrysoparia. Mean and SE of habitat variables measured at Fort Hood, Texas, USA, between habitats where golden-cheeked warblers were and were not detected. Dbh: diameter at breast height. See 'Materials and methods' for definitions of the height strata

\begin{tabular}{|c|c|c|c|c|c|c|}
\hline \multirow{2}{*}{ Habitat variable } & \multicolumn{3}{|c|}{ - Occupied- } & \multicolumn{3}{|c|}{-Unoccupied } \\
\hline & Mean & SE & $\mathrm{N}$ & Mean & SE & $\mathrm{N}$ \\
\hline Juniper density $\mathrm{m}^{-2}$ & 0.031 & 0.01 & 34 & 0.02 & 0.01 & 61 \\
\hline Juniper dbh & 17.27 & 1.13 & 34 & 16.29 & 1.01 & 61 \\
\hline Dbh all species & 17.42 & 0.83 & 34 & 16.84 & 0.78 & 61 \\
\hline Juniper total cover (\%) & 127.75 & 10.39 & 34 & 112.85 & 8.45 & 61 \\
\hline Other woody species total \% vegetative cover & 60.80 & 8.07 & 34 & 94.21 & 9.41 & 61 \\
\hline Ratio juniper/other woody species & 4.14 & 0.79 & 34 & 3.04 & 0.81 & 58 \\
\hline \multicolumn{7}{|l|}{ Juniper cover (\%) } \\
\hline Stratum A & 26.02 & 3.16 & 34 & 23.48 & 2.54 & 61 \\
\hline Stratum B & 37.5 & 3.37 & 34 & 31.88 & 2.50 & 61 \\
\hline Stratum C & 40.66 & 3.69 & 34 & 34.14 & 2.83 & 61 \\
\hline Stratum D & 21.56 & 3.20 & 34 & 20.78 & 2.49 & 61 \\
\hline Stratum E & 2.00 & 0.72 & 34 & 2.54 & 0.81 & 61 \\
\hline \multicolumn{7}{|l|}{ Ratio juniper/other woody species } \\
\hline Stratum A & 5.56 & 1.57 & 34 & 3.83 & 0.95 & 61 \\
\hline Stratum B & 6.90 & 2.25 & 34 & 6.82 & 1.87 & 61 \\
\hline Stratum C & 7.49 & 1.42 & 34 & 4.38 & 1.36 & 61 \\
\hline Stratum D & 4.87 & 2.24 & 34 & 1.88 & 0.44 & 61 \\
\hline Stratum E & 0.22 & 0.15 & 34 & 0.19 & 0.10 & 60 \\
\hline \multicolumn{7}{|l|}{ Total vegetative cover (\%) } \\
\hline Stratum A & 45.23 & 3.99 & 34 & 48.54 & 3.19 & 61 \\
\hline Stratum B & 51.41 & 3.52 & 34 & 54.50 & 3.33 & 61 \\
\hline Stratum C & 51.22 & 3.96 & 34 & 55.21 & 3.24 & 61 \\
\hline Stratum D & 31.95 & 4.57 & 34 & 38.51 & 3.72 & 61 \\
\hline Stratum E & 8.73 & 2.64 & 34 & 10.29 & 2.14 & 61 \\
\hline Total vegetative cover (\%) & 188.55 & 11.26 & 34 & 207.06 & 10.63 & 61 \\
\hline Canopy closure (\%) & 77.42 & 4.08 & 34 & 75.49 & 3.31 & 61 \\
\hline Herbaceous cover $(\%)$ & 6.54 & 3.15 & 34 & 5.01 & 1.03 & 61 \\
\hline Graminoid cover $(\%)$ & 11.05 & 2.44 & 34 & 13.82 & 2.37 & 61 \\
\hline Litter cover (\%) & 68.10 & 4.90 & 34 & 67.87 & 3.17 & 61 \\
\hline Bare ground-rock cover (\%) & 16.61 & 3.36 & 34 & 16.41 & 2.53 & 61 \\
\hline
\end{tabular}

the cover of Ashe juniper and total cover in the lower canopy. PC-4 described a difference in the age and size of the Ashe juniper that comprised the habitat.

We used logistic regression to analyze the strength of the relationship between habitat variables (PCs) and golden-cheeked warbler occurrence. Of the 4 PCs, only PC-1 (gradient in stand composition) showed a significant relationship between golden-cheeked warbler occurrence and habitat $(\mathrm{p}<0.05$, estimate 0.43 , odds ratio 1.54 ). These results indicated that the odds of golden-cheeked warbler detection significantly increased as the ratio of Ashe juniper to other species increased (i.e. PC-1).

\section{DISCUSSION}

In general, the habitat where we detected goldencheeked warblers at Fort Hood was consistent with other habitat descriptions for the species. Most references to golden-cheeked warbler habitat state that they are restricted to mature Ashe juniper-oak wood- land habitat (e.g. Lockwood 1996, Jetté et al. 1998, Dearborn \& Sanchez 2001, DeBoer \& Diamond 2006, Peak 2007). However, there were many locations within Ashe juniper-oak woodlands at Fort Hood where we did not detect golden-cheeked warblers, which suggests that there are other fine-scale and broad-scale features that may determine habitat occupancy. Our analysis was focused on identification of fine-scale variability in mature Ashe juniper-oak woodland habitat characteristics that may influence occupancy. Broader, landscape-scale features were not evaluated in this analysis

The 4 readily interpretable PCs used in our analysis explained $52 \%$ of the total variance in the habitat variables. The variables with high loadings in each of these components were all related to the species composition and structure of the tree component of the habitat (Table 2). These results suggest that goldencheeked warblers tend to favor heavily wooded habitats that contain both Ashe juniper and hardwood species. Other regional studies also reported that Ashe juniper was the most important species in golden- 
Table 2. Dendroica chrysoparia. Loadings for the first 4 principal components (PCs) of 27 habitat variables measured at 95 potential golden-cheeked warbler habitat locations. Components were analyzed with the Varimax method (SYSTAT Software). Bold variables were used to interpret and name PCs. Dbh: diameter at breast height. See 'Materials and methods' for definitions of the height strata

\begin{tabular}{|c|c|c|c|c|}
\hline Habitat variables & $\begin{array}{c}\text { PC-1 } \\
\text { Ratio Ashe juniper } \\
\text { to hardwoods }\end{array}$ & $\begin{array}{c}\text { PC-2 } \\
\text { Total cover } \\
\text { upper canopy }\end{array}$ & $\begin{array}{c}\text { PC-3 } \\
\text { Ashe juniper } \\
\text { cover lower canopy }\end{array}$ & $\begin{array}{c}\text { PC-4 } \\
\text { Age-size of } \\
\text { Ashe juniper }\end{array}$ \\
\hline Percentage explained by rotated PCs & 16.48 & 12.32 & 12.08 & 11.24 \\
\hline Juniper density $\mathrm{m}^{-2}$ & 0.37 & 0.18 & 0.16 & 0.53 \\
\hline Juniper dbh & -0.04 & 0.08 & 0.06 & 0.86 \\
\hline Dbh all species & 0.14 & 0.00 & 0.10 & 0.87 \\
\hline Juniper total cover $(\%)$ & 0.48 & 0.35 & 0.59 & 0.41 \\
\hline Other woody species total \% vegetative cover & -0.65 & 0.38 & 0.07 & -0.21 \\
\hline Ratio juniper/other woody species & 0.89 & -0.05 & -0.01 & 0.14 \\
\hline \multicolumn{5}{|l|}{ Juniper cover $(\%)$} \\
\hline Stratum A & 0.41 & 0.01 & 0.72 & 0.03 \\
\hline Stratum B & 0.46 & 0.15 & 0.66 & 0.31 \\
\hline Stratum C & 0.47 & 0.32 & 0.32 & 0.53 \\
\hline Stratum D & 0.16 & 0.73 & 0.14 & 0.49 \\
\hline Stratum E & 0.04 & 0.29 & 0.11 & 0.16 \\
\hline \multicolumn{5}{|l|}{ Ratio juniper/other woody species } \\
\hline Stratum A & 0.81 & 0.08 & 0.07 & -0.01 \\
\hline Stratum B & 0.83 & 0.01 & -0.01 & -0.03 \\
\hline Stratum C & 0.64 & -0.19 & -0.01 & 0.23 \\
\hline Stratum D & 0.32 & 0.26 & 0.04 & 0.23 \\
\hline Stratum E & 0.08 & -0.02 & 0.02 & -0.01 \\
\hline \multicolumn{5}{|l|}{ Total vegetative cover $(\%)$} \\
\hline Stratum A & -0.28 & -0.12 & 0.78 & -0.01 \\
\hline Stratum B & -0.07 & 0.15 & 0.80 & 0.15 \\
\hline Stratum C & 0.17 & 0.64 & 0.25 & 0.23 \\
\hline Stratum D & -0.13 & 0.92 & -0.03 & 0.03 \\
\hline Stratum E & -0.22 & 0.55 & -0.09 & -0.35 \\
\hline Total vegetative cover (\%) & -0.16 & 0.66 & 0.60 & 0.01 \\
\hline Canopy closure $(\%)$ & 0.07 & 0.18 & -0.01 & 0.11 \\
\hline Herbaceous cover (\%) & -0.21 & -0.08 & -0.03 & 0.04 \\
\hline Graminoid cover $(\%)$ & 0.17 & -0.10 & -0.05 & -0.01 \\
\hline Litter cover (\%) & 0.01 & 0.12 & 0.18 & 0.01 \\
\hline Bare ground-rock cover (\%) & 0.02 & -0.02 & 0.06 & 0.03 \\
\hline
\end{tabular}

cheeked warbler habitat, with oaks playing an important role in foraging (Kroll 1980, Ladd 1985). Logistic regression showed that PC-1 (ratio of Ashe juniper to other species) had the strongest and only statistically significant relationship with golden-cheeked warbler occurrence. Prior unpublished research conducted at Fort Hood indicated that habitat selection by goldencheeked warblers might be influenced by the presence of large contiguous patches of mixed woodlands, with a 3:2 ratio of evergreen/deciduous vegetation and a heterogeneous canopy (G. H. Eckrich pers. comm.). We found that golden-cheeked warbler detections were more likely in habitats with higher ratios of Ashe juniper (approximately 4:1), but other species, primarily oaks, were always present (Table 1).

Golden-cheeked warblers generally construct nests 3 to $7 \mathrm{~m}$ off the ground and rarely forage $<2 \mathrm{~m}$ off the ground (Ladd \& Glass 1999, Dearborn \& Sanchez 2001). Our study did not specifically identify nesting or foraging locations. However, our data suggest that golden-cheeked warblers are selecting stands with a higher ratio of Ashe juniper to other species, especially in the mid- to upper canopy (4 to $8 \mathrm{~m}$ ), which generally corresponds to previously reported nesting and foraging locations.

At Fort Hood, Dearborn \& Sanchez (2001) found that breeding habitat of golden-cheeked warblers was limited to Ashe juniper-oak woodlands with a minimum of $75 \%$ canopy closure. Dearborn \& Sanchez (2001) also reported significant differences in canopy closure when comparing nest sites to paired non-nest sites, although they speculated that the difference was an artifact of how canopy closure was measured at nest sites. Our data did not show a significant relationship between golden-cheeked warbler detection and canopy closure, although our data for mean canopy closure for both occupied and unoccupied habitat was $>75 \%$. 
Our primary objective for this study was to identify fine-scale differences in habitat variables between occupied and unoccupied golden-cheeked warbler locations. Overall, we found that few of the habitat variables measured at the West Fort Hood study site differed between occupied and unoccupied goldencheeked warbler locations within the general Ashe juniper-oak woodland. However, our data indicate that a 4:1 ratio of Ashe juniper to other woody species is an important feature of golden cheeked-warbler habitat, particularly in the mid- to upper canopy at Fort Hood, Texas. These data indicate that the conservation and development of mature oak-Ashe juniper woodlands with the proper ratio of Ashe juniper to other species could improve golden-cheeked warbler habitat within existing woodland patches.

Acknowledgements. We thank R. Murray, K. Convery, E. Wolf, S. Keane, and J. Thompson for valuable field assistance. We also thank R. Peak and R. Kostecke for valuable comments on earlier versions of this manuscript.

\section{LITERATURE CITED}

Anders A, Dearborn D (2004) Population trends of the endangered golden-cheeked warbler at Fort Hood, Texas, from 1992-2001. Southwest Nat 49:39-47

Dearborn D, Sanchez L (2001) Do golden-cheeked warblers select nets locations on the basis of patch vegetation? Auk 118:1052-1057

DeBoer T, Diamond D (2006) Predicting presence-absence of the endangered golden-cheeked warbler (Dendroica chrysoparia). Southwest Nat 51:181-190

Hayden T, Cornelius J, Weinberg H, Jette J, Melton R (2001) Endangered species management plan for Fort Hood, Texas: FY 01 - 05. Tech Rep ERDC/CERL TR-01-26. US Army Corps of Engineers, Champaign, IL

Jetté L, Hayden T, Cornelius J (1998) Demographics of the golden-cheeked warbler (Dendroica chrysoparia) on Fort Hood, Texas. Tech Rep USACERL 98/52. US Army Corps of Engineers, Champaign, IL

Editorial responsibility: Lian Koh,

Zurich, Switzerland
Kroll C (1980) Habitat requirements of the golden-cheeked warbler: management implications. J Range Manag 33: 60-65

Ladd C (1985) Nesting habitat requirements of the goldencheeked warbler. MS thesis, Southwest Texas State University, Austin, TX

Ladd C, Glass L (1999) Golden-cheeked warbler (Dendroica chrysoparia). In: Poole A, Gill F (ed) The birds of North America, No. 420. The Birds of North America, Inc., Philadelphia, PA

Lockwood M (1996) Courtship behavior of golden-cheeked warblers. Wilson Bull 108:591-592

Magness D, Wilkins R, Hejl S (2006) Quantitative relationships among golden-cheeked warbler occurrence and landscape size, composition and structure. Wildl Soc Bull $34: 473-479$

Mueller-Dombois D, Ellenberg H (1974) Aims and methods of vegetation ecology. John Wiley \& Sons, New York, NY

Peak R (2007) Forest edges negatively affect golden-cheeked warbler nest survival. Condor 109:628-637

Pulich W (1976) The golden-cheeked warbler. Texas Parks and Wildlife Department, Austin, TX

Ralph C, Sauer J, Droege S (1995a) Preface: Monitoring bird populations by point counts. In: Ralph C, Sauer J, Droege $\mathrm{S}$ (eds) Monitoring bird populations by point counts. Pacific Southwest Research Station, Forest Service, US Department of Agriculture, Albany, CA

Ralph C, Sauer J, Droege S (1995b) Managing and monitoring birds using point counts: standards and applications. In: Ralph C, Sauer J, Droege S (eds) Monitoring bird populations by point counts. Pacific Southwest Research Station, Forest Service, US Department of Agriculture, Albany, CA

Tazik DJ, Cornelius JD, Herbert DM, Hayden TJ, Jones BR (1992) Biological assessment of the effects of military associated activities on endangered species at Fort Hood, Texas. US Army Construction Engineering Research Laboratories (USACERL) Tech Rep SR EN-93/01, US Army Corps of Engineers, Champaign, IL

Tazik D, Cornelius J, Abrahamson C (1993) Status of the black-capped vireo at Fort Hood, Texas, Vol 1. Distribution and abundance. Tech Rep EN-94/01, US Army Corps of Engineers, Champaign, IL

USFWS (1992) Golden-cheeked warbler (Dendroica chrysoparia) recovery plan. Carol J (ed) US Fish and Wildlife Service, Albuquerque, NM

Submitted: July 11, 2010; Accepted: February 12, 2010

Proofs received from author(s): May 13, 2010 